\title{
Mass Migration and the Polynesian Settlement of New Zealand
}

\author{
Richard Walter ${ }^{1} \cdot$ Hallie Buckley ${ }^{2}$ Chris Jacomb ${ }^{1}$ • \\ Elizabeth Matisoo-Smith ${ }^{2}$
}

(C) The Author(s) 2017. This article is an open access publication

\begin{abstract}
This paper reintroduces the concept of mass migration into debates concerning the timing and nature of New Zealand's settlement by Polynesians. Upward revisions of New Zealand's chronology show that the appearance of humans on the landscape occurred extremely rapidly, and that within decades settlements had been established across the full range of climatic zones. We show that the rapid appearance of a strong archaeological signature in the early 14th century $\mathrm{AD}$ is the result of a mass migration event, not the consequence of gradual demographic growth out of a currently unidentified earlier phase of settlement. Mass migration is not only consistent with the archaeological record but is supported by recent findings in molecular biology and genetics. It also opens the door to a new phase of engagement between archaeological method and indigenous Maori and Polynesian oral history and tradition.
\end{abstract}

Keywords Polynesia $\cdot$ New Zealand · Colonisation · Migration · Indigenous history

\section{Introduction}

The Austronesian colonisation of the Pacific commenced around $3500 \mathrm{BP}$ and culminated, nearly three millennia later, in a $3000 \mathrm{~km}$ journey south of tropical East Polynesia into the temperate and sub-Antarctic waters of New Zealand. This is one of the longest known ocean voyages of the preindustrial age and marks the point at

Richard Walter

richard.walter@otago.ac.nz

1 Department of Anthropology and Archaeology, University of Otago, Dunedin, New Zealand

2 Department of Anatomy, University of Otago, Dunedin, New Zealand 
which the natural world of an isolated Polynesian archipelago began its transformation into a cultural domain (Fig. 1). The history of islands always commences with a single contact event, and Maori society, like other Polynesian societies, recognises this fact in the fundamentals of ideology and socio-political structures. For Maori, the principles of political organisation, legitimacy and succession, of land tenure and identity itself are grounded in the traditions of the ancestral voyaging canoes that travelled from the mythical homeland of 'Hawaiiki', their crew and their landfall. It is not surprising, then, that archaeological attention has been intensely focussed on colonisation and settlement issues since its inception in New Zealand.

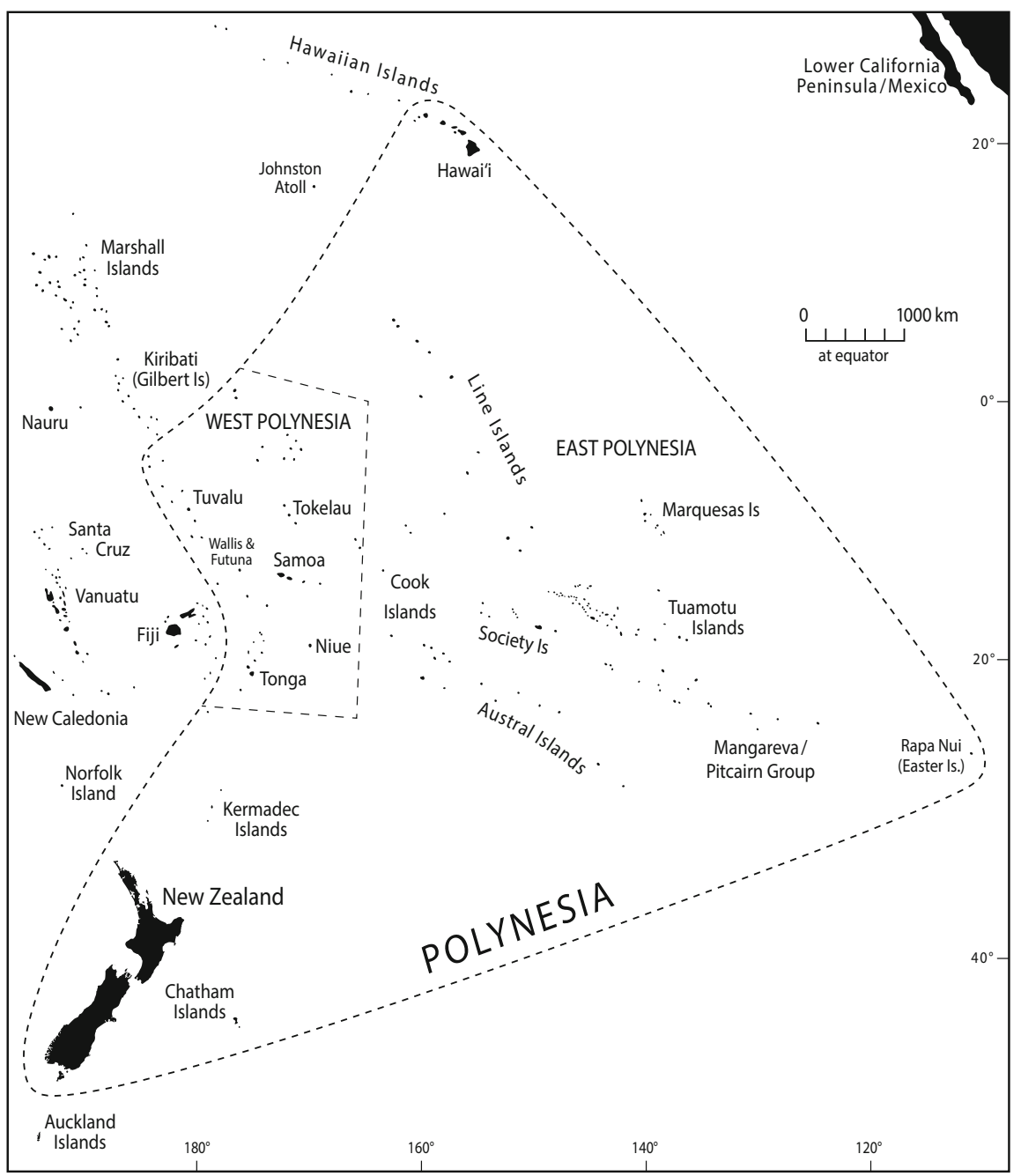

Fig. 1 Map of Polynesia showing the East Polynesian area including Aotearoa (New Zealand) 
For many decades archaeologists interested in colonisation and culture change in Maori society used oral histories and voyaging traditions as aids to interpreting archaeological site data. Oral histories were typically structured around the principles of tribal organisation that prevailed in the 19th century and the stories revolved around the actions of semi-autonomous lineage groups descended from eponymous ancestors acting under the leadership of powerful chiefs (Ballara 1998). History was a constantly changing mosaic of tribal influences, fortunes and grievances as groups formed or broke strategic alliances, fought battles, moved into new areas following conquest or alliance, or split into new tribal units. All of these historical events were charted against whakapapa - the lines of genealogical decent that lie at the heart of Maori social identity and history, and which establish relationships between individuals and different social groups (Barlow 1994; Metge 1976). In the 19th and early 20th century traditionalist scholars such as S. Percy Smith (Smith 1904; Smith et al. 1913) synthesised disparate traditions and fragments of whakapapa gathered from different parts of the country to create historical narratives that more closely accorded with European notions of history. Archaeologists would draw on these narratives to explain an archaeological phenomenon by matching their site data to key events in the narratives, such as the arrival of a particular tribal group in an area or phases of warfare associated with named chiefs and such like (e.g., Duff 1942, 1950).

By the late 1960s the focus shifted to archaeological science, and traditionalist thinking gave way to evolutionary and ecological theory. Out of this shift, a general framework for understanding New Zealand prehistory emerged by the 1970s, of which aspects are still influential. According to this framework, a relatively small number of colonists bearing a tropically-adapted lifestyle and material culture left their tropical homeland of Hawaiiki in one or several journeys and arrived on the shores of New Zealand, with the first landfalls occurring around 800 AD (Sorrenson 1979 , p. 45). There followed a formative period of adaptation and population growth over several centuries, during which time the Polynesian settlers explored new landscapes, modified their tropical subsistence systems and learned to exploit the resource base of a new climate and ecology. Sites from this early period are often referred to as 'Archaic Phase' sites. Artefacts at these sites include finelymade stone adzes and flaked stone assemblages; fishing gear made of bone, stone and shell; and personal ornaments in bone, ivory, shell, tooth and stone (Golson 1959). These artefacts are part of a wider 'Archaic East Polynesian' or 'Early East Polynesian' material culture assemblage that is found in the earliest sites from the Cook Islands through much of French Polynesia (Bellwood 1970; Duff 1950; Sinoto 1970; Fig. 1). Horticulture was part of the 'Archaic Phase' economy but was restricted to northern New Zealand for climatic reasons. The middens of this period reflect a rich, broad-spectrum subsistence economy involving the exploitation of inshore fish and shellfish species, as well as the hunting of marine and terrestrial birds (many now extinct) and marine mammals. One of the most important targets of early Polynesian hunting activities was moa (Aves: Dinornithiformes). These giant flightless birds of the ratite group were endemic to New Zealand but related to other ratites including ostriches, rhea, emu, tinamou and cassowary. Ratites evolved in the super-continent of Gondwana as flighted birds (Maderspacher 2017; Worthy 
and Holdaway 2002) and dispersed before losing flight. Moa are the only descendant species with no vestigial wings and include nine known species, the largest of which weighed up to $230 \mathrm{~kg}$ and stood nearly four metres in height with neck upstretched. Moa were plentiful in New Zealand upon Polynesian arrival but were extinct within a century as a result of hunting and habitat loss (Anderson 1989a, b; Holdaway et al. 2014, Perry et al. 2014). Following moa extinction and the declining viability of hunting in the early 15 th century, horticultural production became increasingly important and there was a population shift to northern zones. By 1500 AD 'Classic' Maori society-the society encountered by the 18th century explorer Captain James Cook-was developing (Davidson 1984; Green 1963, 1975).

The chronology for this narrative was based on radiocarbon dating, but the timing of key events correlated well with estimates based on whakapapa and genealogical reckoning (e.g., Rivers 1910). The key assumptions were that New Zealand was settled by a relatively small number of people and that classical Maori society emerged from its tropical Polynesian roots after centuries of gradual adaptation and culture change. In this model the primary drivers of cultural success were demographic growth and ecological adaptation-similar processes to those used to model the success and expansion of non-human coloniser species.

In the late 1980s improvements in archaeological science started to undermine the foundations of the standard narrative. The earliest radiocarbon dates were shown to be poorly supported (Anderson 1991) and none of the 'Archaic' sites could be confidently dated to earlier than 1300 AD. Furthermore, Holdaway and Jacomb (2000) showed that the extinction of moa occurred with astonishing rapidity, in a matter of 80-100 years, not after centuries of relentless human predation. Reluctant to relinquish 500 years, or half of New Zealand's history, archaeologists began to wonder if there was a lengthy missing record and sought to test this proposition by re-dating sites and seeking proxy evidence of an earlier human presence in the palaeoenvironmental record (Sutton 1987). This endeavour met with limited success. Several decades later there is still no convincing direct evidence of humans on the New Zealand landscape any earlier than $1300 \mathrm{AD}$, although some archaeologists believe that earlier horizons are yet to be found in New Zealand, or are represented in known sites at the low-probability ends of some radiocarbon calibration curves. Claims of indirect evidence of earlier settlement in the form of anthropogenic influences on landscapes remain ephemeral (e.g., Beavan and Sparks 1998; Higham et al. 2004; Holdaway 1996; Wilmshurst and Higham 2004). It is now apparent that sites containing both moa bone as food remains and artefacts of tropical East Polynesian form date no earlier than the first decades of the 14th century and decline by the beginning of the 15th. Unfortunately, this period represents a particularly wiggly portion of the radiocarbon calibration curve, creating regions of ambiguity (Hogg et al. 2013; McFadgen et al. 1994) that make it difficult to resolve sites into a tight chronological sequence. For the purposes of this paper, however, we define a colonisation phase as a period approximately congruent with the 14th century AD, during which migrants from tropical East Polynesia and two or three generations of their descendants established a stable and self-reliant colony in New Zealand. 
Today, most archaeologists accept the reality of a shorter chronology, but the discipline as a whole has not fully explored the implications of this in relation to colonisation and culture-change processes. In this paper we propose a 'strategic migration' model for New Zealand that re-evaluates cultural, biological and behavioural aspects of Polynesian colonisation in light of the archaeological record as it is now understood. It has two parts. First, we argue that New Zealand was the target of a planned mass migration out of tropical East Polynesia in the early 1300s. By migration we mean the deliberate movement of populations in what were essentially one-way voyages from the tropical Pacific to New Zealand. In that sense our definition differs from that of Anderson (2003, pp. 71-72), who reserves the term migration for movement between existing populations while using dispersal to refer to expansion through fissioning (the outcome in both cases being colonisation). By referring to this as a 'planned' event we mean that the scale of the endeavour in terms of cost and technology, and the number of participants involved, implies prior knowledge of the destination and strong, well-defined motives. As discussed below, the migration does not seem to have been ecologically or demographically driven, which leaves socially defined agendas as the most probable motivating factors (e.g., Anderson 2006). Second, we show that during the colonisation phase the migrants adopted a systematic and coordinated strategy for the exploration of New Zealand and the establishment of a network of viable communities linked by regular interaction.

We do not argue here that no one visited New Zealand or lived there prior to the 14th century. Instead we argue that the sudden and widespread appearance of sites in the 14th century is the result of mass migration and the adoption of a particular set of colonisation strategies; it is not the outcome of demographic growth out of a currently invisible earlier population base. Below we discuss the two aspects of our model. We first look at the evidence for mass migration and then we look at colonisation behaviours through the lens of the 14th century archaeological record. Much of the archaeological evidence we will be drawing on in support of our strategic migration model comes from excavations at the site of Wairau Bar in the northern South Island (Fig. 2). This 14th century village site provides strong support for the mass migration hypothesis, and documents the range of strategies that were adopted by the first colonists to establish a stable colony. We briefly review the Wairau Bar site before turning to the evidence for mass migration.

\section{Wairau Bar}

The Wairau Bar site is located on the southern side of the Wairau and Opawa river mouths, at the northern end of a long boulder bank that encloses the Wairau lagoons. The location appears bleak and windswept today, with poor soils and no fresh water, but for colonisers equipped with efficient coastal and offshore water craft its location had great economic and strategic advantage. Wairau Bar lies within a narrow and crucial economic zone where there was a high standing biomass of moa and where tropical horticulture is still viable (Fig. 3). It is also located within a few days' canoe travel of the important stone sources of Nelson and D'Urville Island, 


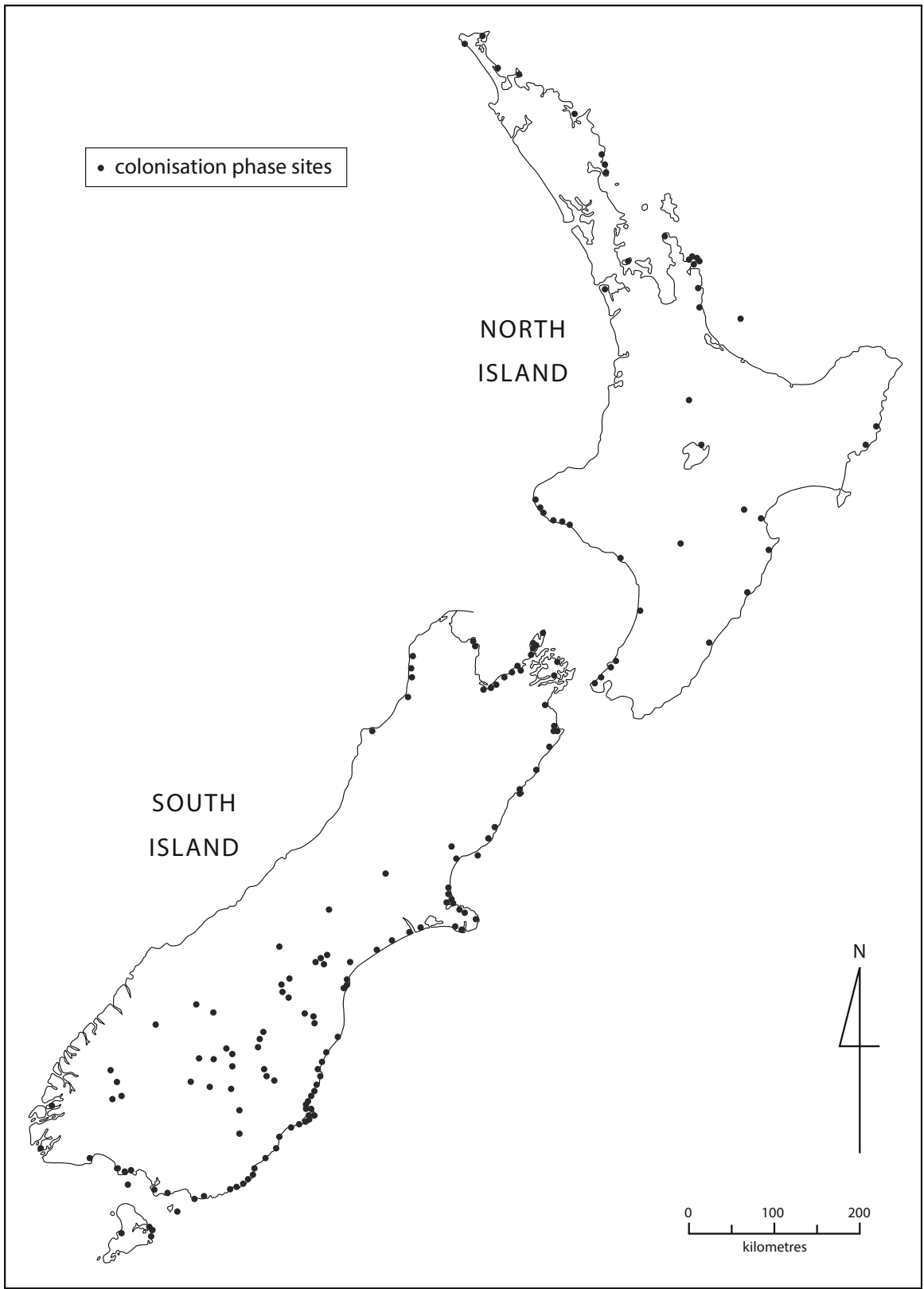

Fig. 2 Sites that have evidence of some combination of moa remains as a food source, 'archaic' artefact forms or radiocarbon dates indicating occupation in the fourteenth century. Includes most of the 'moa hunting' sites identified by Anderson (1989a, b, pp. 111, 121, 142) 
Argilite sources, used for the large scale production of high quality adzes which were widely distributed in national exchange networks by $1350 \mathrm{AD}$.

Horticultural zone - for production of Maori staple food crop, kumera (Ipomoea batatas).

Terrestrial hunting zone - zone where there was a maximum reliance on moa hunting based on moa bone abundance levels in archaeological sites.

Wairau Bar site. Early 14th C. village (>11 ha in size) A type site for New Zealand and East Polynesian 'Archaic'. Site contains a rich faunal and material culture record, evidence of adze production, exchange connections throughout New Zealand and cemetery zones containing the burials of high ranked individuals including some born in Hawaiiki.

Potential coastal travel routes showing Cook Strait as occupying position of maximum access to New Zealand coastlines.

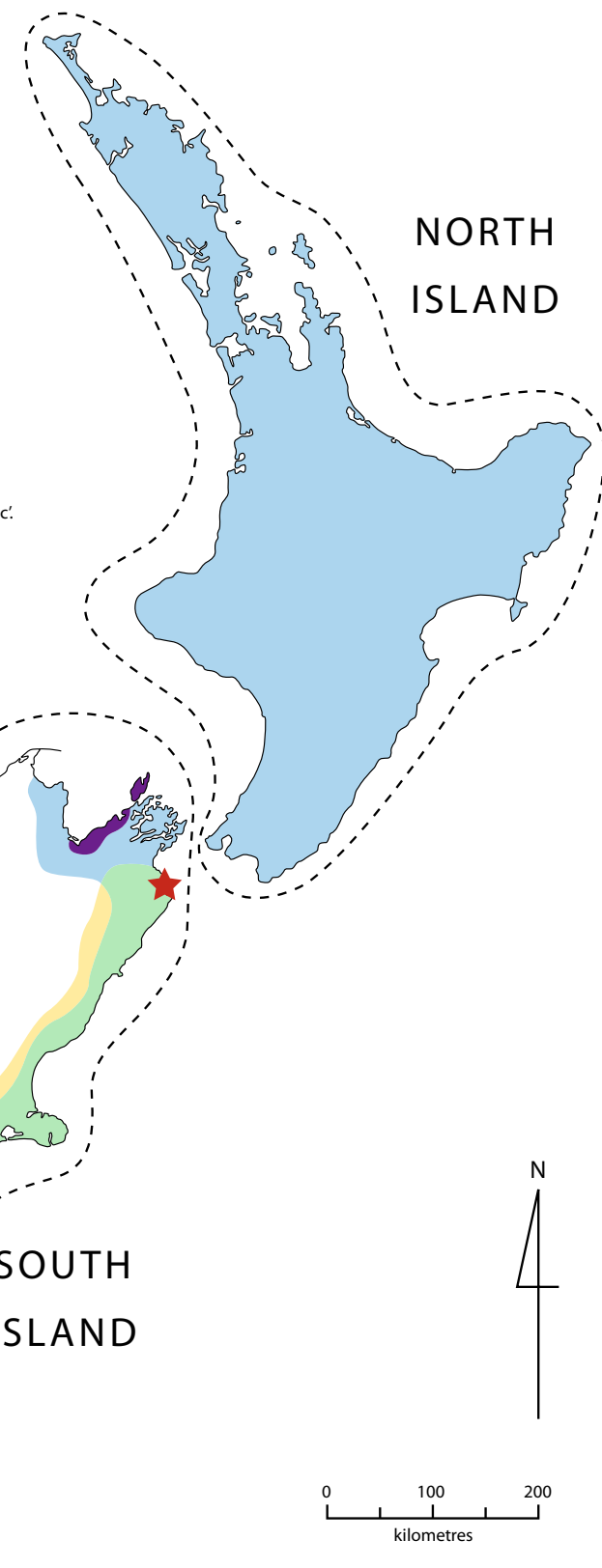

Fig. 3 Zonation map showing Wairau Bar in a prime location in relation to key resources and coastal communication networks 
and its location on Cook Strait maximises the community's access to all the coastlines of the country. Like the modern capital Wellington, which is located on the opposite shores of Cook Strait, Wairau Bar occupies a highly advantageous natural position within a national coastal voyaging network.

The site was discovered by fossickers in the 1920s and has been the subject of excavations by the Canterbury Museum (1942-1964) and, more recently, by the authors (Brooks et al. 2011). Excavations uncovered a vast and diverse assemblage of early East Polynesian ('Archaic') style artefacts, including finely flaked stone adzes; personal ornaments made of shell, dentalium, bone, tooth and stone; and fishing equipment. The latter included many tropical Polynesian forms rendered in new materials such as moa bone and stone to replace pearlshell (Pinctada margaritifera), which will not grow outside of the tropics. Excavations also revealed small tools: tattooing chisels, awls, needles, hammer stones, files and abraders. Thousands of unmodified flakes, pieces of debitage and worked adze preforms were also found, often in high-density activity areas. These attest to the role of Wairau Bar in the early stone adze industry: adze preforms brought in from the fine-grained argillite sources of Nelson and D'Urville Island were made into finished forms that were widely used on site. These tools are also found in 14th century sites across much of the county (Prickett 1989; Turner 2000; Walls 1974; Walter et al. 2010), and Wairau Bar may well have been a centre for their manufacture and export.

The midden assemblage was equally rich and diverse, containing the bones of many extinct species of bird (including moa) as well as sea mammals, domestic dogs, fish and shellfish. Wairau Bar is unique in New Zealand in terms of its size, the diversity and abundance of material culture, and the richness of midden fauna. It contains the greatest displays of personal and community wealth of any site in the country, and the strongest evidence for connection to the homeland (Hawaiiki). Indeed, the early Wairau Bar excavations established the origins of Maori culture in East Polynesia and the site has been variously described as the type site for the 'Moa Hunter Period of Maori Culture' and for the New Zealand 'Archaic' (Duff 1950; Golson 1959). It is also one of the most intensively dated sites in Pacific archaeology. Higham et al. (1999) published what has been considered for many years to be the definitive age estimate based on dates on moa eggshell from ten of the human burials, and from marine shell midden samples. The results were interpreted as indicating commencement of occupation in the late 13th century AD. Subsequently Jacomb et al. (2014) published the results of a high-precision dating study of a single cooking and discard event, based on moa eggshell dates using Bayesian calibration. The results placed that event in the period 1320-1350 AD at two standard deviations. In fact, the probability spans of the Higham et al. (1999) and Jacomb et al. (2014) dates overlap, and all have their highest probabilities in the 14th century, with tails that stretch into the late 13th century (Jacomb et al. 2014, p. 29). Thus it is most likely that Wairau Bar was settled in the first decades of the 14th century - not necessarily the earliest occupation site in the country, but settled close to the beginning of the colonisation phase. The feature dated by Jacomb et al. (2014) was constructed some time later, but before 1350. The full size of the site at the time of occupation is not known, but 11 ha of intact deposit has been identified 
in geophysical survey, and ground tested (Brooks et al. 2011, figure 31). There is no significant stratigraphic complexity and the site is best interpreted as a large village that was occupied for decades but not centuries.

The most obvious comparisons with Wairau Bar, in terms of size, settlement pattern, function, diversity and richness of artefact and faunal collections, are the colonisation phase ('Archaic') sites of tropical East Polynesia, including Hane, Ha'atuatua and Hanamiai (Marquesas); Urei'a and Anai'o (Cook Islands); and Vaito'otia/Fa'ahia and Maupiti (Society Islands) (Allen and Steadman 1990; Conte and Molle 2014; Emory and Sinoto 1964; Rolett 1998; Sinoto 1979; Sinoto and Kellum 1965; Suggs 1961; Walter 1998). Like those sites, Wairau Bar was a permanent village, located to provide safe access for deep-water sailing craft by residents who were participating in long-distance voyaging and exchange networks. Wairau Bar not only mirrors those sites in setting and site content, it contains evidence of direct contact with the islands of tropical Polynesia. In 2010 a chisel made of the shell of the marine shellfish species Acus crenulatus was identified in an assemblage of artefacts excavated in February 1947 (Davidson et al. 2011, p. 95). Acus crenulatus is a tropical species not found in New Zealand waters and the tool must have been brought out with the migrants from Hawaiiki. The direct connection to tropical Polynesia is further evidenced in the human burial data.

Wairau Bar is one of the rare sites in Polynesia to contain a large and relatively well-preserved cemetery zone and it therefore provides the best representation we have of a founding population (Buckley et al. 2010). There are a minimum of 42 human burials at Wairau Bar and they are generally described as falling into three burial clusters. Group 1 comprises eight individuals (five males, one female, and two undetermined) and is considered to represent the earliest burial phase at the site. An analysis of the stable isotope signatures of carbon and nitrogen in bone collagen and strontium in tooth enamel in the Group 1 individuals indicated that some may have spent some of their early years in Hawaiiki before travelling to New Zealand. The first two isotope signatures are associated with diet and the latter with the underlying geology of the place where the individuals resided during childhood (Katzenberg 2001; Montgomery 2010; Pollard 2011; Schwarcz and Schoeninger 1991). Kinaston et al. (2013) determined that the carbon and nitrogen stable isotope ratios indicated that the Group 1 individuals had had (at some point within the decade or so preceding death) diets with a much lower diversity of protein sources that those of the other individuals on site. The latter displayed a dietary pattern that suggested the exploitation of a wide range of protein sources-such as might be expected in the earliest stages of settlement in a new ecology-and which is well reflected in the midden data from Wairau Bar (Kinaston et al. 2013, p. 6). They proposed that the Group 1 result is a reflection of an earlier dietary phase prior to arriving in New Zealand. The Group 1 individuals display a similar dietary trend to individuals from Hanamiai, a colonisation-phase site in the Marquesas, tropical East Polynesia (Kinaston et al. 2013, p. 7). The Group 1 individuals also differed significantly from the other individuals in terms of strontium isotope ratios, although these could represent '... a wide variety of potential bedrock sources within New Zealand and abroad, including a mixture of basalt and limestone typical of Oceanic islands in TEP [tropical East Polynesia] and the North Island of New Zealand' 
(Kinaston et al. 2013, p. 8). Most of the individuals outside of Group 1 had strontium isotope signatures that were close to those determined for the local environment, based on determinations of the archaeological dog population from the site. The Group 1 individuals were identified as 'immigrants' to the site (along with two males from outside that group). In summary, the Wairau Bar population was comprised of individuals of different origins. The Group 1 individuals all shared a geologically similar origin and a similar diet, with less diversity of protein sources, probably depending on meat sourced from a lower trophic level (i.e., not marine mammal). Without more precise strontium baseline maps from New Zealand and the Pacific it is not possible to determine where the Group 1 individuals spent time prior to their arrival at Wairau Bar, but the overall evidence, including the archaeology, makes the assumption of a youth spent in Hawaiiki reasonable.

\section{Migration}

For the last 50 years or so archaeologists have tended to regard migration as a theoretically questionable explanation for culture change (van Dommelen 2014). Yet before the 1960s, migration theory dominated discussions of culture change (Anthony 1990), and this was certainly true in New Zealand. For example, the early traditionalist scholar S. Percy Smith (Smith 1904; Smith et al. 1913) used Maori origin traditions to synthesise a pan-Maori migration narrative, which rapidly become entrenched as a national foundation story. In this narrative, New Zealand was discovered by a named Polynesian navigator around 800 AD; it was revisited several times from Hawaiiki (including by the famous Maori explorer Kupe) before being colonised by a fleet of canoes (referred to as the 'Great Fleet' in various New Zealand traditions) around $1350 \mathrm{AD}$, whose captains became the eponymous founders of today's tribes (Smith et al. 1913; Sorrenson 1979, p. 45).

The influence of 'traditionalism' and migration theory declined in New Zealand archaeology as scholars showed that the popular sagas of Maori history, including the Great Fleet, had been at least partly constructed through the misrepresentation and manipulation of indigenous text (Davidson 1984, p. 10; Simmons 1969, 1976; Simmons and Biggs 1970; Sorrenson 1977, 1979). The growing influence of the New Archaeology, with its emphasis on process, its marginalisation of historical explanation and individual agency, and its promotion of ecological explanation, also played a role in the waning popularity of migration theory (Burmeister 2000, p. 539). By the 1980s 'migration' and 'migrant' had virtually dropped from the archaeological vocabulary in New Zealand except as gloss terms for the first settlers (e.g., Davidson 1984, pp. 1, 222). However, the shorter chronology that now prevails has brought the topic of migration to the fore again, and there are a number of reasons why mass migration provides an attractive explanation for the peopling of New Zealand. The first of these is archaeological and draws evidence from the distribution and patterning of the earliest known sites on the landscape. The second is demographic and relies on genetic data to provide an estimate of the size of the founding cohort. The third cites an aDNA study of members of an early generation 
of migrants that provides information about the nature of the biological pool from which the colonists derived.

The most obvious argument for mass migration lies in the patterns of 14th century site distribution. Figure 2 shows the location of sites assigned to the colonisation phase (as defined above) and includes all those sites that meet Anderson's (1989b, p. 110) criteria as 'moa hunting' sites. The sites shown in Fig. 2 span no more than a century but are distributed over $12,000 \mathrm{~km}$ of coastline, from the temperate and sub-tropical north to the sub-Antarctic coastlines of Stewart Island and Foveaux Strait. There is insufficient time for this distribution pattern to be the result of demographically driven expansion and it is best interpreted as evidence of a sudden influx and rapid spread of populations. Anderson (1991, p. 790) was also aware of the implications of a rapid widespread appearance of sites, and noted that planned mass migration-not unlike the Norse settlement of Greenland - could not be ruled out as an explanation. However, Anderson favoured colonisation commencing in the 12th century (1991, p. 792) and envisaged a longer time depth for the 'Archaic', making a mass migration a less compelling option and one that was never subsequently adopted in New Zealand archaeology. More recently he has suggested a phase of migration-although not a planned mass migration-over a period of a century commencing in the late 1200s (Anderson 2014, p. 67).

Other demographic and biological factors also lend support to a 14th century mass migration. It is generally accepted (e.g., Pool 1991) that Captain Cook's estimate of the Maori population in 1769 of around 100,000 individuals was reasonably accurate. In a 1990 paper, Brewis et al. modelled Maori population demographics with a view to understanding the timing of colonisation. They set a population size at contact of 150,000 people and a founder group size of around 50 individuals (Brewis et al. 1990, p. 343). To achieve a contact period population level of 150,000 using a reasonable population growth model (they assumed a sigmoidal growth curve with rates starting at 3\%-4\% and dropping to around $1 \%$ following an interruption in food supply around 1400 AD), a colonisation date of $500 \mathrm{AD}$ or earlier was required (Brewis et al. 1990, pp. 352-353). In light of recent archaeological investigations none of these propositions seems credible. If, instead, we accept a colonisation event in the early 1300s, a growth rate of only around $1 \%$ will easily result in a population of 100,000 at contact if the founder group size is increased to 500 people. This is a conservative growth rate for a colonising population below environmental carrying capacity (Steele et al. 1998). Furthermore, the figure of 500 individuals is not arbitrary; it is consistent with recent estimates of the founder group size based on the analysis of the genetic variability of modern Maori populations. Using computer simulations of 'realistic' growth rate models and the analysis of mtDNA from Maori and Polynesian subjects, Whyte et al. (2005) estimated that at least 190 females must have been present in the founding canoes. This is double an earlier estimate based on similar methods by Murray-McIntosh et al. (1998). Migration often involves some gender selection, and ethnographic and historical evidence shows that males are generally more mobile than women (Burmeister 2000, p. 543), so 500 is likely a conservative estimate of founding group size. 
Further evidence for a mass migration event comes from our initial studies of the mitochondrial genomes of the Wairau Bar burials. These have indicated a surprising level of mtDNA variation, with at least three of the four individuals sequenced, providing evidence that they were not directly maternally related (Knapp et al. 2012). This included the two individuals we sequenced from Group 1: Burial 1, the only female, and Burial 2.1, a young adult male. As our work continues, we are finding additional mtDNA haplotypes, with at least four different maternal lineages now identified in Burial group 1. This clearly indicates that these individuals were not full siblings or the descendants of female siblings. While our understanding of the level of mtDNA diversity in Pacific populations is changing rapidly with increased sampling in the regions (Duggan et al. 2014), such levels of diversity in a founding population indicate that this was not a small, closely related matrilineal or matrilocal colonising group sampled from a single village or even a single island; if the individuals buried at Wairau Bar were not the very first generation of colonists, then the likely founding female population could have been even larger-all data that support a mass migration scenario.

\section{Colonisation}

The second part of our 'strategic migration' model is concerned with colonisationthe spread and establishment of populations, and the process of connecting them into a socially and economically viable colony. There are various possible models for the colonisation of an unoccupied landscape. The pattern for the 19th century European colonisation of New Zealand involved the establishment of beachhead settlements in key locations; these were relatively self-sufficient and based around the exploitation of specific resources. Some were short-lived (sojourner) ventures abandoned within decades. Others received new migrants, diversified economically, became linked by coastal networks and served as centres for population expansion (Smith 2008, pp. 370-373). Although the key elements of these three processesestablishment of bases, building connectivity and population expansion-all occurred during the Polynesian colonisation in the 14th century as well, the difference is that in the earlier colonisation period they occurred concurrently. The Polynesian colonisation phase was characterised by high levels of mobility and low levels of population isolation. It involved the rapid exploration of New Zealand's coastlines and rivers, the establishment of a widely dispersed pattern of settlements, and ongoing connectivity across the wider colony. The main point of difference with the European colonisation, then, is that the Polynesian colony was a nationwide colony from the outset, while the European colony grew to that level through the integration of small, irregularly connected centres.

The clearest evidence for an early phase of rapid and effective exploration comes from the record of lithic resource exploitation. In a large, continental landmass like New Zealand, where industrial resources are widely distributed and where the first settlers would have had little or no prior knowledge of their location, technical properties, procurement parameters or potential value, one would expect there to be a lag between first settlement and the appearance of these resources in 
archaeological sites. In fact, no such lag is apparent in the archaeological record. Instead the range of industrial resources found in colonisation-phase sites strongly suggests that a systematic exploration programme was established immediately upon arrival, which resulted in the rapid acquisition of geographical knowledge and the establishment of an exchange or communication network linking sites around the country. Indeed, early explorers did not just map out New Zealand coastal waters in the colonisation phase but were exploring far offshore. Obsidian from the Mayor Island source in the North Island has now been identified in sites from this period on the Kermadec Islands, Norfolk Island, the Chatham Islands and subAntarctic Auckland Island (Fig. 1; Walter et al. 2010, p. 504).

Figure 4 shows the location of industrial lithic resources known to have been in use within the 14th century and, as far as the radiocarbon record will allow, most seem to have been in use by around $1350 \mathrm{AD}$. Although these sources represent only a sub-set of all the industrial-grade stone available, they represent the highest quality materials used in all major tool categories. Not only were these premier resources discovered rapidly, their distribution shows that an effective network linking settler communities developed within, at most, decades. Perhaps the best case study for the rapid discovery and efficient re-distribution of raw materials in a coastal exchange system is obsidian sourced from Mayor Island. Mayor Island lies $28 \mathrm{~km}$ from the mainland in the Bay of Plenty and contains thick reefs and boulder deposits of obsidian of very high quality. Mayor Island obsidian has been identified in the earliest deposits of colonisation-phase sites up to $2000 \mathrm{~km}$ from source; from the northern tip of the North Island to Foveaux Strait and Stewart Island in the extreme south of New Zealand (Seelenfreund-Hirsch 1985; Walter et al. 2010). Coastal exploration would have been facilitated by the use of the double-hulled vessels brought from Hawaiiki, and fluvial boulder deposits at river mouths would have provided clues about inland resources to explorers knowledgeable in stone technology. In Hawaiiki these craft were the medium by which communication and exchange networks linked communities on distant islands and archipelagos (Weisler et al. 2016), and they appear to have been put to the same use in New Zealand's colonisation phase (Weisler and Walter 2017). Thus exploration, population dispersal, and the emergence of communication networks - processes which might be expected to occur sequentially in a new land-occurred rapidly and concurrently in New Zealand.

An important consideration for migrants is the availability of support services (Boyd 1989), and migrant communities frequently value and endeavour to maintain links to the homeland for this purpose. These relationships can be long-lasting and cover very long distances, and this is a phenomenon that has already been well documented in the archaeology of the Lapita colonisation of the Pacific (Green and Kirch 1997; Kirch 1988; Lilley 2000; Specht 2002). Social networks provide a means of transferring information and materials between migrant and homeland communities, but they frequently involve a ritual dimension, including elements of ritual exchange and religious and symbolic behaviours (Burmeister 2000, p. 344). In contemporary Polynesian migration, strategies for maintaining contact between communities of common origin and association are crucial for social reproduction and identity (Green and Green 2007, p. 251). The same would have been true in 


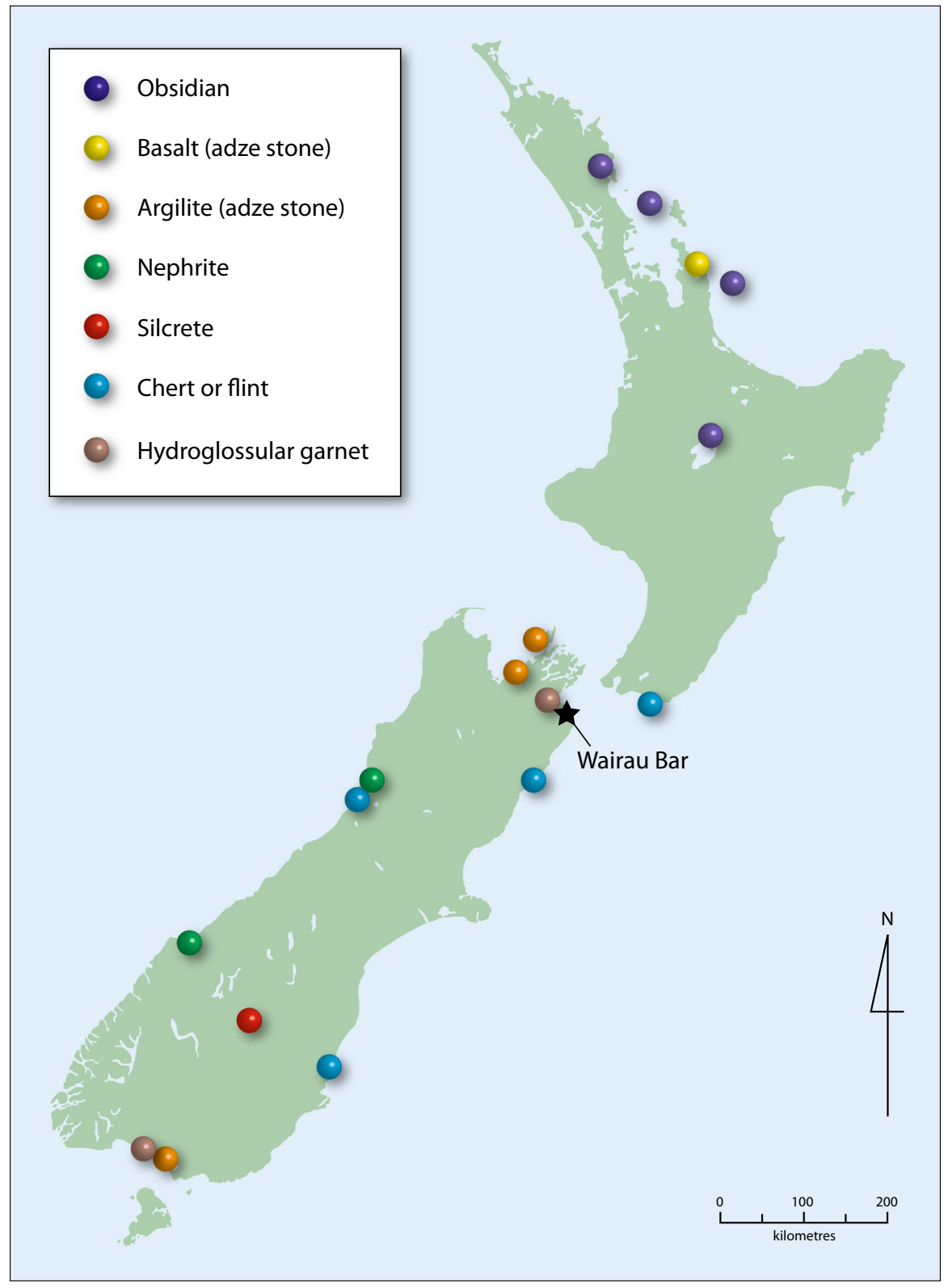

Fig. 4 Sources of stone known to have been used in the first half of the fourteenth century and which were moved in exchange networks over distances of hundreds to more than $2000 \mathrm{~km}$

colonial New Zealand, but the tropical homeland could not provide those services. Connectivity would have provided part of the solution, but within networks, central places often emerge as social, cultural and economic loci. Because of those special features of the site noted above, it has long been imagined (Anderson 2014; 
Davidson 1984; Duff 1950) that Wairau Bar played some singular role in New Zealand's early history. We suggest that the role of the site may have changed over decades from being simply one of a number of sites established early on in the colonisation phase, to becoming a central place in the new colony (e.g., Nakoinz 2010). Its emergence as a central place within the colonial network is demonstrated

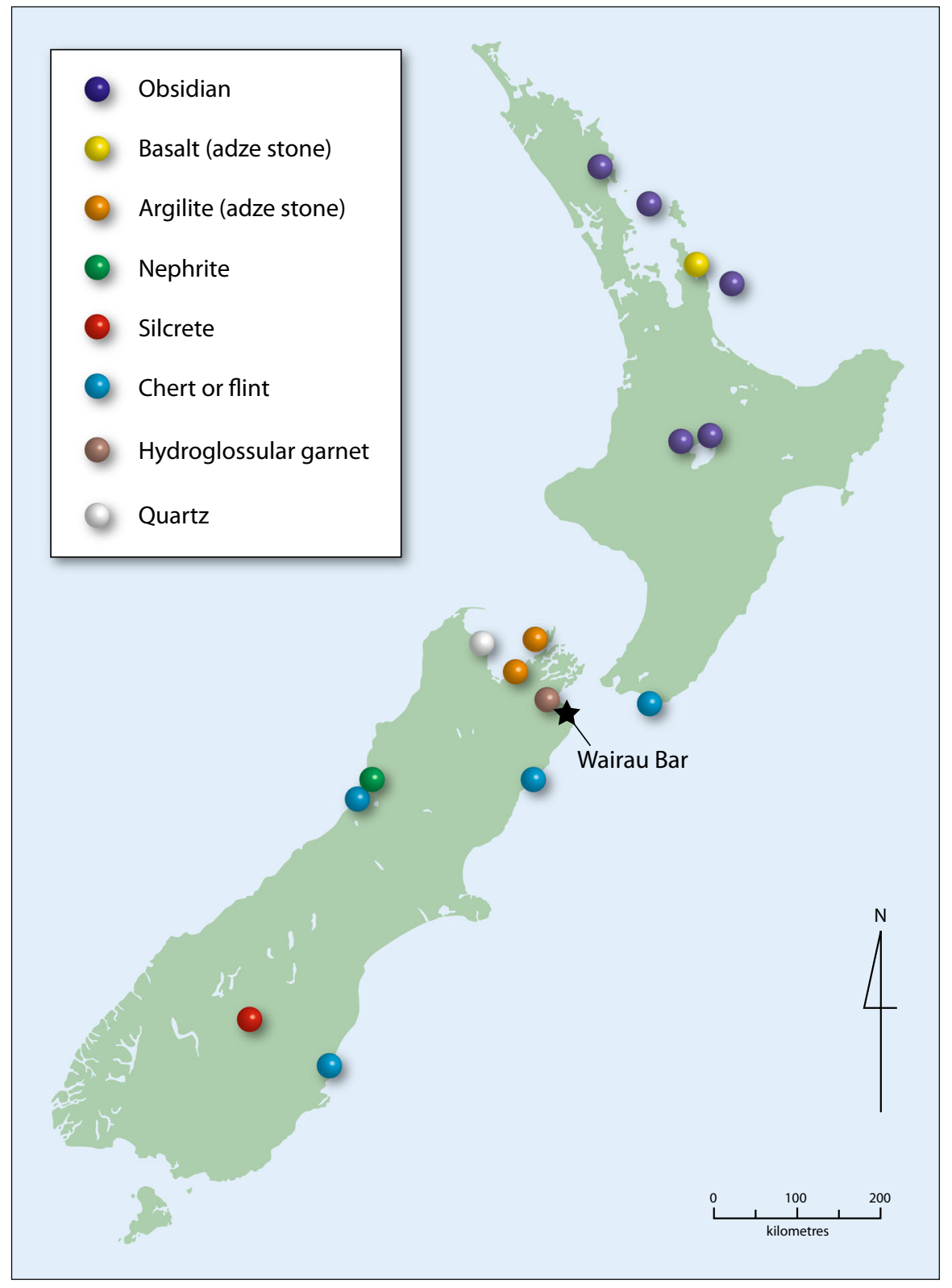

Fig. 5 Sources of stone from which artefacts have been identified at the Wairau Bar site 
Table 1 Matrix of approximate linear distance in kilometres between contemporary settlement zones travelling by canoe over shortest coastal and riverine routes

\begin{tabular}{lrrrrrrrrrr}
\hline & A & B & C & D & E & F & G & H & I & J \\
\hline A. Wairau Bar & 0 & & & & & & & & & \\
B. D'Urville Island & 113 & 0 & & & & & & & & \\
C. Redcliffs & 272 & 385 & 0 & & & & & & & \\
D. Buller Mouth & 426 & 313 & 698 & 0 & & & & & & \\
E. Otago Peninsula & 646 & 759 & 374 & 1072 & 0 & & & & & \\
F. Catlins & 825 & 938 & 553 & 906 & 179 & 0 & & & & \\
G. Palliser Bay & 123 & 139 & 395 & 452 & 769 & 948 & 0 & & & \\
H. Taupo & 963 & 979 & 1235 & 1292 & 1609 & 1788 & 951 & 0 & & \\
I. Coromandel & 1022 & 1037 & 1294 & 1350 & 1668 & 1847 & 899 & 1196 & 0 & \\
$\quad$ Peninsula & & & & & & & & & & \\
J. Bay of Islands & 1213 & 1229 & 1485 & 1542 & 1859 & 2038 & 1173 & 922 & 274 & 0 \\
Total distance & 5603 & 5892 & 6691 & 8051 & 8935 & 10,022 & 5849 & 10,935 & 10,587 & 11,735 \\
\hline
\end{tabular}

at one level by the range of non-local industrial materials accessed by the community. Figure 5 shows the source locations of tools recovered from Wairau Bar; this is nearly the full range of material known to have been in use in 14th century New Zealand. A simple matrix of linear distance between contemporary settlement zones provides more empirical evidence of the site's centrality (Table 1).

Central places play key roles (social, economic, ritual). Ongoing research into the early adze industry by the authors suggests that one of the roles of Wairau Bar may have been as a manufacturing and distribution centre for high quality adzes (Shipton et al. 2016). In the absence of direct connections to the islands of East Polynesia, it is possible that Wairau Bar also served as a local reference point and symbolic connection to the tropical homelands. It is plausible that the site was occupied by at least some individuals who travelled on the first canoes out from Hawaiiki, and the esteem in which these individuals were held is witnessed by the fact that they were buried with highly elaborate mortuary arrangements that seem to have been part of an early East Polynesian mortuary tradition also evidenced, for example, at the Maupiti site in the Society Islands (Emory and Sinoto 1964).

One of the most powerful lines of evidence that Wairau Bar was a ritual or symbolic centre for the new colony comes from the excavation of an oven pit and midden complex in the 2009 excavations by the authors. Geophysical survey had identified a cluster of five circular features at the site, one of which was selected for test excavation and proved to be a boulder-lined oven pit, $6 \mathrm{~m}$ in diameter and $1.2 \mathrm{~m}$ deep, refilled with midden (Brooks et al. 2011, p. 48). A 5\% sample of the infill deposit contained 61 species of shellfish, bird (including four species of moa), sea mammal and fish. It also contained 1135 fragments of moa eggshell, representing at least 31 individual eggs from three species (Emeus curtus, Emeus crassus, and Dinornis robustus) (Oskam et al. 2011). Jacomb et al. (2014, p. 25) have demonstrated that the midden remains derive from a single cooking and discard episode and have argued that the oven feature was constructed and used as 
part of a ritual feasting event. There are five ovens in total within the cluster, suggesting that ritual feasting was a regular occurrence in this precinct of the site. The two most common social events associated with ritual feasting in Maori society today are funerals and political investitures. Given the location of this cluster of ovens no more than $60 \mathrm{~m}$ from the Group 1 burials, it is tempting to suggest that the two are related, although there is no direct evidence to make that argument. However, the size and scale of consumption implied by the midden remains raises the possibility that the event may have brought visitors in from distant settlementsin much the same way that tangihanga (Maori funeral customs) or investitures do today.

Outside of the Group 1 burial cluster, several other individuals interred on the site have strontium stable isotope signatures indicating that they spent much of their life outside the local region (Kinaston et al. 2013, p. 7). It is possible that they either moved to Wairau Bar late in life, or were returned there after death for burial. Either possibility supports the notion that the site enjoyed special status within the early colony and also hints at continuity in some aspects of Maori funeral practices and attitudes to place of origin (Oppenheim 1973).

\section{Discussion}

We commenced this paper by pointing out that the upward revision of New Zealand's chronology leaves little time for a gradual growth in population levels prior to the appearance of a strong archaeological signature in the early to mid 14th century. That is not to say that we reject the possibility of some pre-14th century settlement, but we do contend that there is no strong evidence for this and that such evidence is unnecessary to explain the extraordinarily rich record. In our view, the current data is not a partial and biased fragment, but a representative and well preserved account of New Zealand's Polynesian settlement. It documents a mass migration in the 14th century followed by a planned and well-executed colonisation. We are aware that in invoking migration (and especially 'mass migration') we are reintroducing an explanatory framework that many archaeologists consider theoretically questionable. But mass migration is a useful concept in New Zealand colonisation research; not only is it consistent with the archaeology, it solves the problem of assuring colony viability in long-distance, one-way migration, and it provides an opportunity to revisit the role of indigenous history and tradition.

For humans to survive economically, culturally, socially and reproductively, they must operate within the framework of a community. In modern and historical settings, where the basic unit of migration is the family or small groups of individuals, success is dependent upon the presence of established community support structures and frameworks (Boyd 1989). When groups colonise previously unoccupied territories, 'units of migration must be large enough to create a viable community, or individuals/families must migrate between established communities' (Cameron 2000, p. 555). The latter is not an option in New Zealand. In fact, New Zealand is one of a very few cases in world migration where the homeland could not provide any support services and such services were locally unavailable-at least in 
the first years of settlement. Colonisation had to be self-supporting and this was achieved through three processes. First, it required the movement of sufficient people to create a functioning community, including enough diversity to provide marriage partners of appropriate biological and social distance; second, it required high levels of connectivity to link the dispersed settler groups; and third, it depended on one or more central places to provide a diversity of services via the medium of a communication network. The model we have presented here implies higher levels of central planning and management than are usually assumed in Polynesian migration theory, and this raises the question of motivation.

Discussions of the causes of migration have traditionally revolved around the concepts of push and pull: 'in general, migration is most likely to occur when there are negative (push) stresses in the home region and positive (pull) attractions in the destination region, and the transportation costs between the two are acceptable' (Lee 1966, p. 899). Archaeologists are not entirely confident that either demographic or ecological factors 'pushed' Polynesians to colonise, and have tended to look for explanation in social processes such as 'founder rank expansion', where junior lineages could establish seniority in new territories, for example (Bellwood 2013, p. 197). Identifying the proximate cause of an archaeological migration event is notoriously difficult (Anthony 1990, p. 898), although this is a domain where oral history and tradition make claims to knowledge. Archaeologists, for good reason, rejected the over-simplified models of the past based on earlier naive treatments of traditional history (see above). But the problem of dismissing the Great Fleet and other migration 'traditions' is that, regardless of their literal veracity, they deal with concepts that are vital to understanding migration, such as motive, planning, leadership, decision making and agency. If we are to understand anything of the causes and social processes of migration in the New Zealand case, archaeologists need to reconsider the role of oral history and tradition.

One of the primary areas where oral tradition has been consulted for information on the settlement of New Zealand is the question of origins-from where did the migrants embark on their voyages of discovery and colonisation? Unfortunately, the traditional Maori sources have not been explicitly helpful: they either refer to the mythological Polynesian homeland of 'Hawaiiki' or reference a diverse assortment of island names. Of those place names which are actually congruent with known locations, most tend to be generic terms that exist in cognate forms throughout Polynesia (Grey 1855; Smith 1904; Taumoefolau 1996). In fact, the concept of 'Hawaiiki' as a homeland from which founding ancestors travelled out to found colonies on newly discovered islands is one that occurs throughout many of the islands of Polynesia (Kirch and Green 2001). In East Polynesia the concept of Hawaiiki is a particularly compelling one for archaeologists, as geochemical sourcing studies have demonstrated the existence of a community of interaction that stretched from the Southern Cooks in the west, through French Polynesia to the Marquesas in the east, and southeast to Mangareva. Within this zone there was sufficient interaction up until and including the 14th century to leave a very clear archaeological signature (Weisler et al. 2016; Weisler and Walter 2017). The material culture of this region and time period is also sufficiently similar and distinctive to be referred to as the Archaic or Early East Polynesian assemblage (see 
above). Thus we can refer to this entire region as 'Hawaiiki' and describe it as a period and place of relative prosperity and innovation, when long-distance voyaging linked islands into a dispersed community of culture. In light of this, Walter (1994) has suggested that rather than seeing the imprecision in Maori traditions as obscuring the question of origins, it accurately reflects the regional origins of the voyaging canoes. In terms of pinning down the origin of the voyaging canoes that actually landed in New Zealand, archaeological, biological (Matisoo-Smith et al. 1998) and linguistic (Clark 1979) evidence suggests a region encompassing at least the southern Cook, Austral and eastern Society Islands (Fig. 6). This is a region previously defined as the 'Hawaiiki Zone' for Maori (Walter 1994). What inspired people from Hawaiiki to migrate to New Zealand is another matter, but it is reasonable to assume that the first prerequisite for migration is knowledge, since migrants are unlikely to move to areas about which they have no information (Brown et al. 1977). In the New Zealand case, where transport costs are extraordinarily high, the body of information circulating in Hawaiiki must have been especially compelling to inspire a mass migration event.

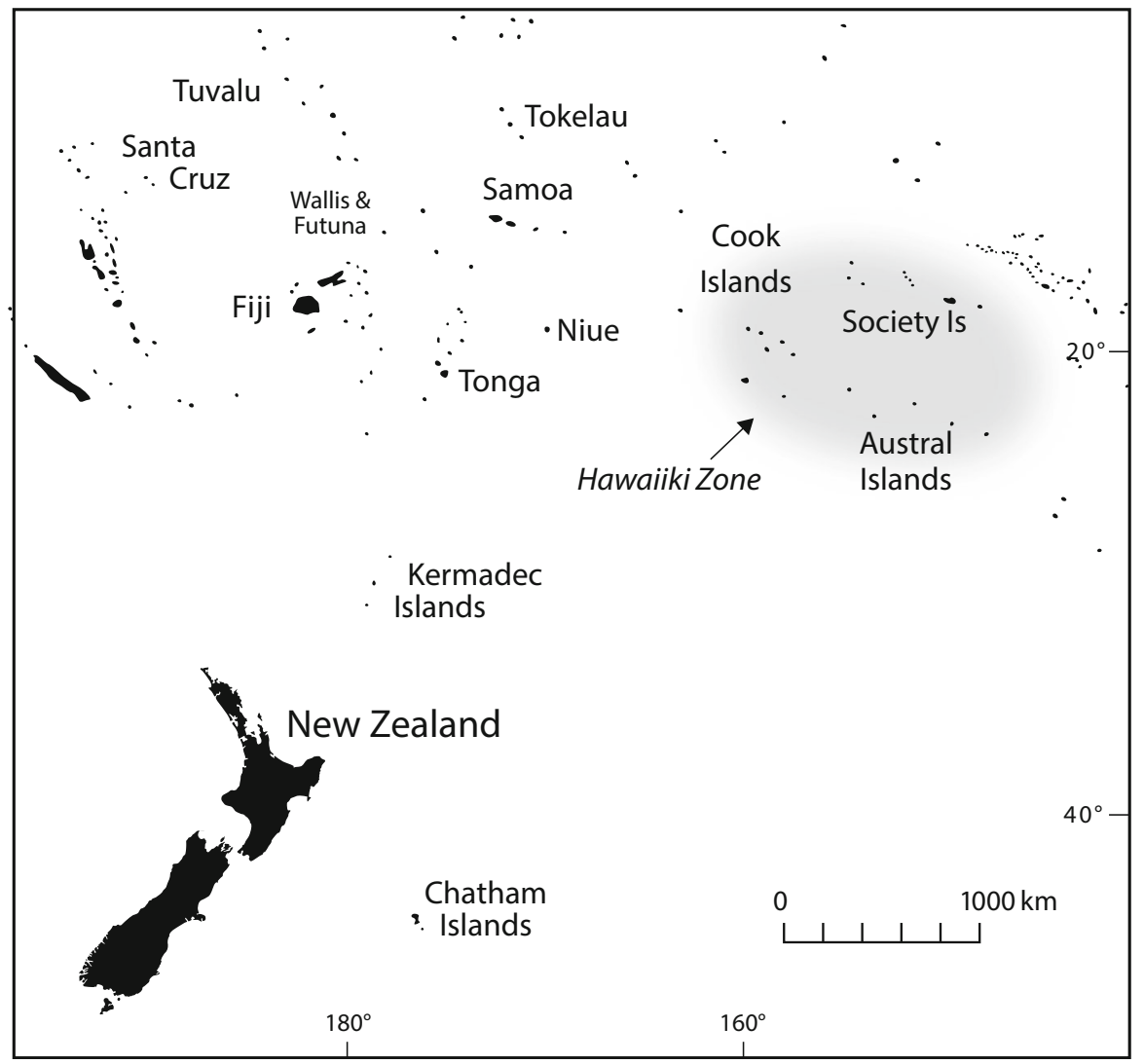

Fig. 6 Location of Hawaiiki Zone-the zone where the first Polynesian settlers of New Zealand originated 
Pacific archaeologists normally consider colonisation to have been a stadial process in which the first stage is concerned with knowledge acquisition (Anderson 1995; Graves and Addison 1995; Irwin 1992). This 'discovery' stage involves the initial location and perhaps exploration of a new land followed by return voyaging. A 'colonisation' phase involves the establishment of resident populations. Irwin (1992, p. 57) argues that there would normally be a time gap between discovery and colonisation and we might expect that the greater the distances and costs involved, the longer the gap would be. Here the parallels with the traditionalist models are compelling: regardless of the details, Maori tradition is clear that exploratory voyaging preceded migration by at least several generations-enough time for knowledge to circulate and build momentum within the networks of communication and exchange of Hawaiiki. Nevertheless, knowledge of the existence of a bountiful place, especially in the absence of significant demographic and environmental pressures, is not in itself enough to motivate a mass migration, especially one with social and economic costs as high as those underpinning the settlement of New Zealand. Here oral traditions again provide a clue.

Whether we can read the canoe traditions as direct or partial accounts of historical events, there is a consistent theme running through all Maori text that places prime causes for epochal events in the hands of individuals of extraordinary charisma, mana (authority) and ability to draw on deep-seated Polynesian traditions and structures to recruit others into their vision. We have seen this pattern play out historically with 19th century Maori leaders such as Te Rauparaha (Burns 1980; Te Rauparaha and Butler 1980) and Te Kooti (Binney 1995), who drew their followers into complex and costly endeavours with radical social, economic and religious implications. The oral traditions of the canoe voyages all document precisely that kind of charismatic leadership driving decision-making in the homelands (Reilly and Walter n.d.). In fact, strong charismatic leaders would have been a prerequisite for mass migration, since building and outfitting even a single ocean-going canoe would have been a colossal economic enterprise involving the mobilisation of dozens of individuals if not communities. The Hawaiiki Zone was a place where wealthy communities possessing deep ocean sailing capabilities were linked by exchange networks that would also have been the medium for the circulation of information and ideas (as well as the stone tools that we use to map those connections). Powerful religious concepts were circulating in the Hawaiiki Zone at around the time of New Zealand's settlement, as is reflected in the growth of the marae complex (Emory 1970; Green 1996; Kahn and Kirch 2014; Kirch 1984; Wallin and Solsvik 2010, pp. 87-88). We will never know with any certainty whether in that setting one or a small number of charismatic secular or religious leaders of vision and determination may have driven and led a mass movement, based at least partly on quality information about a desirable new territory far from home. There is already some evidence, however, that the colonists were recruited from a wide area, a networked community, and were motivated by factors beyond immediate kin needs and aspirations.

Many migrant groups are kin based, giving rise to a migration pattern that Fix (1978) has termed 'kin structured migration' (KSM). So far, the mtDNA data from the Group 1 individuals at Wairau Bar cited above suggests that the colonisation of 
New Zealand was not strongly kin structured. The founder group included individuals who were not closely related maternally, indicating that kinship was not necessarily the primary or only criterion for inclusion in the colony. This pattern has been observed in other colonising groups. For example, the Plymouth Colony displayed lower levels of kin relatedness than would be expected in a typical KSM event (Fix 2012, p. 91; McCullough and Barton 1991). It included many nuclear families but recruitment was over a wide area, and the organising principle of the community and of recruitment was religious philosophy rather than kinship.

In this paper we have argued that the archaeological record of New Zealand is well preserved and offers a sound foundation for the reconstruction of New Zealand's Polynesian colonisation. Regardless of whether there was a small resident population in New Zealand before $1300 \mathrm{AD}$, the archaeological record of the 14th century cannot be explained as a result of centuries (e.g., Sutton 1987)—still less decades - of population growth from this currently invisible colony. Instead, it records a mass movement of people. We contend that this was a planned migration, based on prior knowledge of the location of New Zealand, and that it involved a number of interacting communities within a zone of regular interaction in central East Polynesia. Not only was the migration planned and led by capable leaders, but the colonisation of New Zealand itself was efficient and rapidly executed. The essential strategy of the colonists seems to have been to reproduce the social and economic structures of Hawaiiki in the new land. As in tropical East Polynesia, this involved the establishment of a communication network linking communities on an expanding colonial frontier. Like the Hawaiiki network upon which it was modelled, this became the medium for the dissemination of raw materials, manufactured products such as stone adzes, information, and social support.

Archaeological investigation will probably never tell us about individual motives, ideological drivers or the role of visionary chiefs in the migration and colonisation of New Zealand. But these are precisely the issues that oral tradition addresses and it is now time to take a more nuanced and critical look at these traditions in order to further our understanding of migration, colonisation, and the relationship between early New Zealand and Hawaiiki society.

Acknowledgements We would like to acknowledge the helpful comments and criticisms offered by Karen Greig, Atholl Anderson and anonymous referees. The illustrations were made by Les O'Neil of the Department of Anthropology and Archaeology at the University of Otago.

Open Access This article is distributed under the terms of the Creative Commons Attribution 4.0 International License (http://creativecommons.org/licenses/by/4.0/), which permits unrestricted use, distribution, and reproduction in any medium, provided you give appropriate credit to the original author(s) and the source, provide a link to the Creative Commons license, and indicate if changes were made.

\section{References}

Allen, M. S., \& Steadman, D. W. (1990). Excavations at the Ureia site, Aitutaki, Cook Islands: Preliminary results. Archaeology in Oceania, 25, 24-37. 
Anderson, A. (1989a). The mechanics of overkill in the extinction of New Zealand Moa. Journal of Archaeological Science, 16, 137-151.

Anderson, A. (1989b). Prodigious birds: Moas and moa-hunting in prehistoric New Zealand. Cambridge: Cambridge University Press.

Anderson, A. (1991). The chronology of colonization in New Zealand. Antiquity, 65, 767-795.

Anderson, A. (1995). Current approaches in East Polynesian colonisation research. Journal of the Polynesian Society, 104, 110-132.

Anderson, A. (2003). Initial human dispersal in Remote Oceania: Pattern and explanation. In C. Sand (Ed.), Pacific archaeology: Assessments and prospects (pp. 71-84). Noumea: Département Archéologie, Service des Musées et du Patrimoine.

Anderson, A. (2006). Islands of exile: Ideological motivation in maritime migration. The Journal of Island and Coastal Archaeology, 1, 33-47. doi:10.1080/15564890600579858.

Anderson, A. (2014). Speaking of migration, AD 1150-1450. In A. Anderson, J. Binney, \& A. Harris (Eds.), Tangata Whenua: An illustrated history (pp. 43-67). Auckland: Bridget Williams Books.

Anthony, D. W. (1990). Migration in archeology: The baby and the bathwater. American Anthropologist, 92, 895-914. doi:10.1525/aa.1990.92.4.02a00030.

Ballara, A. (1998). Iwi: The dynamics of Maori tribal organisation from c.1769 to c.1945. Wellington: Victoria University Press.

Barlow, C. (1994). Tikanga whakaaro: Key concepts in Mäori culture. Auckland: Oxford University Press.

Beavan, N. R., \& Sparks, R. J. (1998). Factors influencing C-14 ages of the Pacific rat Rattus exulans. Radiocarbon, 40, 601-613.

Bellwood, P. (1970). Dispersal centers in East Polynesia, with special reference to the Society and Marquesas Islands. In R. C. Green \& M. Kelly (Eds.), Studies in Oceanic culture history (Vol. 1, pp. 93-104). Pacific Anthropological Records, 11. Honolulu: Bishop Museum.

Bellwood, P. S. (2013). First migrants: Ancient migration in global perspective. Chichester: Wiley Blackwell.

Binney, J. (1995). Redemption songs: A life of Te Kooti Arikirangi Te Turuki. Auckland: Auckland University Press.

Boyd, M. (1989). Family and personal networks in international migration: Recent developments and new agendas. International Migration Review, 23, 638-670. doi:10.2307/2546433.

Brewis, A. A., Sutton, D. G., \& Molloy, M. A. (1990). Modeling the prehistoric Maori population. American Journal of Physical Anthropology, 81, 343-356.

Brooks, E., Walter, R., \& Jacomb, C. (2011). History of excavations at Wairau Bar. Records of the Canterbury Museum, 25, 13-58.

Brown, L., Gustavus, S. O., \& Malecki, E. J. (1977). Awareness space characteristics in a migration context. Environment and Behavior, 9, 335-348.

Buckley, H., Tayles, N., Halcrow, S. E., Robb, K., \& Fyfe, R. (2010). The people of Wairau Bar: A reexamination. Journal of Pacific Archaeology, 1, 1-20.

Burmeister, S. (2000). Archaeology and migration: Approaches to an archaeological proof of migration. Current Anthropology, 41, 539-567. doi:10.1086/317383.

Burns, P. (1980). Te Rauparaha: A new perspective. Wellington: Reed.

Cameron, C. (2000). Comments on: Burmeister, S., 'Archaeology and migration: Approaches to an archaeological proof of migration'. Current Anthropology, 41, 555-556. doi:10.1086/317383.

Clark, R. (1979). Language. In J. D. Jennings (Ed.), The prehistory of Polynesia (pp. 249-270). Canberra: Australian National University.

Conte, E., \& Molle, G. (2014). Reinvestigating a key site for Polynesian prehistory: New results from the Hane dune site, Ua Huka (Marquesas). Archaeology in Oceania, 49, 121-136.

Davidson, J. M. (1984). The Prehistory of New Zealand. Auckland: Longman Paul.

Davidson, J., Findlater, A., Fyfe, R., Macdonald, J., \& Marshall, B. (2011). Connections with Hawaiki: The evidence of a shell tool from Wairau Bar, Marlborough, New Zealand. Journal of Pacific Archaeology, 2, 93-102.

Duff, R. (1942). Moa-hunters of the Wairau (pp. 1-42). Canterbury Museum Records. Christchurch: Canterbury College.

Duff, R. (1950). The Moa Hunter period of Maori culture. Wellington: Department of Internal Affairs.

Duggan, A. T., Evans, B., Friedlaender, F. R., Friedlaender, J. S., Koki, G., Merriwether, D. A., et al. (2014). Maternal history of Oceania from complete mtDNA genomes: Contrasting ancient diversity 
with recent homogenization due to the Austronesian expansion. The American Journal of Human Genetics, 94, 721-733.

Emory, K. P. (1970). A re-examination of East-Polynesian marae: Many marae later. In R. Green \& M. Kelly (Eds.), Studies in Oceanic culture history (Vol. 1, pp. 73-93). Pacific Anthropological Records, 11. Honolulu: Bishop Museum.

Emory, K. P., \& Sinoto, Y. H. (1964). Eastern Polynesian burials at Maupiti. Journal of the Polynesian Society, 73, 143-160.

Fix, A. G. (1978). The role of kin-structured migration in genetic microdifferentiation. Annals of Human Genetics, 41, 329-339. doi:10.1111/j.1469-1809.1978.tb01900.x.

Fix, A. G. (2012). Kin-structured migration and colonization. In M. H. Crawford \& B. C. Campbell (Eds.), Causes and consequences of human migration: An evolutionary perspective (pp. 87-100). Cambridge: Cambridge University Press.

Golson, J. (1959). Culture change in prehistoric New Zealand. In J. D. Freeman \& W. R. Geddes (Eds.), Anthropology in the South Seas (pp. 29-74). New Plymouth: Avery.

Graves, M. W., \& Addison, D. J. (1995). The Polynesian settlement of the Hawaiian Archipelago: Integrating models and methods in archaeological interpretation. World Archaeology, 26, 380-399.

Green, R. C. (1963). A review of the prehistoric sequence in the Auckland province. New Zealand Archaeoligcal Association Monograph, No. 2. Auckland: Auckland Archaeological Society.

Green, R. C. (1975). Adaptation and change in Maori culture. In G. Kuschel (Ed.), Biogeography and ecology in New Zealand (pp. 591-641). The Hague: Dr W. Junk.

Green, R. C. (1996). Settlement patterns and complex society in the Windward Society islands. In M. Julien, M. Orliac, \& C. Orliac (Eds.), Mémoire de pierre, mémoire d'homme: Tradition et archéologie en Océanie. Ouvrage collectif en hommage à J. Garanger (pp. 207-226). Paris: Publication de la Sorbonne.

Green, R. C., \& Green, V. (2007). An accent on atolls in approaches to population histories of Remote Oceania. In P. Kirch \& J. L. Rallu (Eds.), The growth and collapse of Pacific Island societies: Archaeological and demographic perspectives (pp. 232-256). Honolulu: Universtiy of Hawaii Press.

Green, R. C., \& Kirch, P. V. (1997). Lapita exchange systems and their Polynesian transformations: Seeking explanatory models. In M. I. Weisler (Ed.), Prehistoric long-distance interaction in Oceania: An interdisciplinary approach (pp. 19-37). Auckland: New Zealand Archaeological Association.

Grey, G. (1855). Polynesian mythology and ancient traditional history of the New Zealand race, as furnished by their priests and chiefs. London: J. Murray.

Higham, T., Anderson, A., \& Jacomb, C. (1999). Dating the first New Zealanders: The chronology of Wairau Bar. Antiquity, 73, 420-427.

Higham, T., Hedges, R., Anderson, A., Bronk Ramsey, C., \& Fankhauser, B. (2004). Problems associated with the AMS dating of small bone samples: The question of the arrival of Polynesian rats to New Zealand. Radiocarbon, 46, 207-218.

Hogg, A. G., Hua, Q., Blackwell, P. G., Niu, M., Buck, C. E., Guilderson, T. P., et al. (2013). SHCal13 Southern Hemisphere calibration, 0-50,000 years cal BP. Radiocarbon, 55, 1889-1903.

Holdaway, R. N. (1996). Arrival of rats in New Zealand. Nature, 384, 225-226.

Holdaway, R., Allentoft, M., Jacomb, C., Oskam, C., Beavan, N., \& Bunce, M. (2014). An extremely low-density human population exterminated New Zealand moa. Nature Communications, 5, 5436. doi:10.1038/ncomms6436.

Holdaway, R. N., \& Jacomb, C. (2000). Rapid extinction of the moas (Aves: Dinorinthiformes): Model, test, and implications. Science, 287, 2250-2254.

Irwin, G. J. (1992). The prehistoric exploration and colonisation of the Pacific. Cambridge: Cambridge University Press.

Jacomb, C., Holdaway, R., Allentoft, M., Bunce, M., Oskam, C., Walter, R., et al. (2014). High-precision dating and ancient DNA profiling of moa (Aves: Dinornithiformes) eggshell documents a complex feature at Wairau Bar and refines the chronology of New Zealand settlement by Polynesians. Journal of Archaeological Science, 50, 24-30. doi:10.1016/j.jas.2014.05.023.

Kahn, J. G., \& Kirch, P. V. (2014). Monumentality and ritual materialization in the Society Islands: The archaeology of a major ceremonial complex in the 'Opunohu Valley, Mo'orea. Bishop Museum Bulletins in Anthropology. Honolulu: Bishop Museum. 
Katzenberg, M. A. (2001). Stable isotope analysis: A tool for studying past diet, demography, and life history. In M. A. Katzenberg \& S. Saunders (Eds.), Biological anthropology of the human skeleton (pp. 413-441). Hoboken: Wiley.

Kinaston, R. L., Walter, R., Jacomb, C., Brooks, E., Tayles, N., Halcrow, S. E., et al. (2013). The first New Zealanders: Patterns of diet and mobility revealed through isotope analysis. PLoS ONE, 8, e64580.

Kirch, P. V. (1984). The evolution of Polynesian chiefdoms. Cambridge: Cambridge University Press.

Kirch, P. V. (1988). Long-distance exchange and island colonization: The Lapita case. Norwegian Archaeological Review, 21, 103-117.

Kirch, P. V., \& Green, R. C. (2001). Hawaiki, ancestral Polynesia: An essay in historical anthropology. Cambridge: Cambridge University Press.

Knapp, M., Horsburgh, K. A., Prost, S., Stanton, J. A., Buckley, H. R., Walter, R. K., et al. (2012). Complete mitochondrial DNA genome sequences from the first New Zealanders. Proceedings of the National Academy of Sciences of the United States of America, 109, 18350-18354. doi:10.1073/ pnas. 1209896109.

Lee, E. S. (1966). A theory of migration. Demography, 3, 47-57.

Lilley, I. (2000). Migration and ethnicity in the evolution of Lapita and post-Lapita maritime societies in northwest Melanesia. Modern Quaternary Research in Southeast Asia, 16, 177-196.

Maderspacher, F. (2017). Evolution: Flight of the ratites. Current Biology, 27, R110-R113. doi:10.1016/j. cub.2016.12.023.

Matisoo-Smith, E., Roberts, R., Irwin, G. J., Allen, J. S., Penny, D., \& Lambert, D. M. (1998). Patterns of prehistoric human mobility in Polynesia indicated by mtDNA from the Pacific rat. Proceedings of the National Academy of Sciences of the United States of America, 95, 15145-15150.

McCullough, J. M., \& Barton, E. Y. (1991). Relatedness and kin-structured migration in a founding population-Plymouth Colony, 1620-1633. Human Biology, 63, 355-366.

Mcfadgen, B. G., Knox, F. B., \& Cole, T. R. L. (1994). Radiocarbon calibration curve variations and their implications for the interpretation of New Zealand prehistory. Radiocarbon, 36, 221-236.

Metge, J. (1976). The Maoris of New Zealand: Rautahi. London: Routledge \& Kegan Paul.

Montgomery, J. (2010). Passports from the past: Investigating human dispersals using strontium isotope analysis of tooth enamel. Annals of Human Biology, 37, 325-346.

Murray-Mcintosh, R. P., Scrimshaw, B. J., Hatfield, P. J., \& Penny, D. (1998). Testing migration patterns and estimating founding population size in Polynesia by using human mtDNA sequences. Proceedings of the National Academy of Sciences of the United States of America, 95, 9047-9052. doi:10.1073/pnas.95.15.9047.

Nakoinz, O. (2010). Concepts of central place research in archaeology. In Kiel Graduate School \& Human Development in Landscapes (Eds.), Landscapes and human development: The contribution of European archaeology. Proceedings of the International Workshop 'Socio-environmental dynamics over the last 12,000 years: The creation of landscapes' (1st-4th April 2009) (Vol. 191, pp. 251-264). Bonn: Universitätsforschungen zur prähistorischen Archäologie.

Oppenheim, R. S. (1973). Maori death customs. Wellington: Reed.

Oskam, C. L., Jacomb, C., Allentoft, M. E., Walter, R., Scofield, R. P., Haile, J., et al. (2011). Molecular and morphological analyses of avian eggshell excavated from a late 13th century earth oven. Journal of Archaeological Science, 38, 2589-2595. doi:10.1016/j.jas.2011.05.006.

Perry, G. L., Wheeler, A. B., Wood, J. R., \& Wilmshurst, J. M. (2014). A high-precision chronology for the rapid extinction of New Zealand moa (Aves, Dinornithiformes). Quaternary Science Reviews, $105,126-135$.

Pollard, A. M. (2011). Isotopes and impact: A cautionary tale. Antiquity, 85, 631-638.

Pool, D. I. (1991). Te Iwi Maori: A New Zealand population past, present and projected. Auckland: Auckland University Press.

Prickett, N. J. (1989). Adzes of Nelson argillite from the far north of New Zealand: The Auckland Museum collection. Archaeology in New Zealand, 32, 135-146.

Reilly, M., \& Walter, R. (in press). Ngā Hekenga Waka: Migration and early settlement. In S. Duncan, G. Leoni, L. Paterson, M. Rātima, M. Reilly, \& L. Carter, (Eds.), Te Kōparapara: An introduction to the Māori world. Auckland: Auckland University Press.

Rivers, W. H. R. (1910). The genealogical method of anthropological inquiry. The Sociological Review, $3,1-12$.

Rolett, B. V.(1998). Hanamiai: Prehistoric colonization and cultural change in the prehistoric New Zealand. Unpublished Ph.D. Thesis, University of Otago. 
Schwarcz, H. P., \& Schoeninger, M. J. (1991). Stable isotope analyses in human nutritional ecology. Yearbook of Physical Anthropology, 34, 288-321.

Seelenfreund-Hirsch, A. (1985). The exploitation of Mayor Island obsidian in prehistoric New Zealand. Ph.D. Thesis, University of Otago.

Shipton, C., Weisler, M., Jacomb, C., Clarkson, C., \& Walter, R. (2016). A morphometric reassessment of Roger Duff's Polynesian adze typology. Journal of Archaeological Science: Reports, 6, 361-375.

Simmons, D. R. (1969). New Zealand myth: Kupe, Toi and the 'Fleet'. New Zealand Journal of History, 3, 14-31.

Simmons, D. R. (1976). The great New Zealand myth. Wellington: Reed.

Simmons, D. R., \& Biggs, B. (1970). The sources of the 'Lore of the Whare-Wananga'. Journal of the Polynesian Society, 79, 22-42.

Sinoto, Y. H. (1970). An archaeologically based assessment of the Marquesas Islands as a dispersal center in east Polynesia. In R. C. Green \& M. Kelly (Eds.), Studies in Oceanic culture history. Papers presented at Wenner-Gren Symposium on Oceanic culture history, Sigatoka, Fiji, August 1989 (Vol. 1, pp. 105-132). Pacific Anthropological Records No. 11. Honolulu: Bishop Museum.

Sinoto, Y. H. (1979). Excavations on Huahine, French Polynesia. Pacific Studies, 3, 1-40.

Sinoto, Y. H., \& Kellum, M. (1965). Preliminary report on excavations in the Marquesas Islands, French Polynesia. Honolulu: Bishop Museum.

Smith, I. (2008). Maori, Pakeha and Kiwi: Peoples, cultures and sequence in New Zealand archaeology. In G. Clark, B. F. Leach, \& S. O'Connor (Eds.), Islands of inquiry: Colonisation, seafaring and the archaeology of maritime landscapes (pp. 367-380). Canberra: Australian National University Press.

Smith, S. P. (1904). Hawaiki: The original home of the Maori; with a sketch of Polynesian history. Christchurch: Whitcombe \& Tombs.

Smith, S. P., Whatahoro, H. T., Matorohanga, T., \& Pohuhu, N. (1913). The lore of the Whare-wānanga: Or, teachings of the Maori College on religion, cosmogony, and history. Memoirs of the Polynesian Society, 3 \& 4. New Plymouth: The Polynesian Society.

Sorrenson, M. P. K. (1977). The whence of the Maori: Some 19th century exercises in scientific method. Journal of the Polynesian Society, 86, 449-478.

Sorrenson, M. P. K. (1979). Maori orgins and migrations: The genesis of some Pakeha myths and legends. Auckland: Auckland University Press.

Specht, J. (2002). Obsidian, colonizing and exchange. In S. Bedford, C. Sand, \& D. Burley (Eds.), Fifty years in the field: Essays in honour and celebration of Richard Shutler Jr's archaeological career. New Zealand Archaeological Association Monograph (pp. 37-49). Auckland: New Zealand Archaeological Association.

Steele, J., Adams, J., \& Sluckin, T. (1998). Modelling Paleoindian dispersals (paleoecology and human populations). World Archaeology, 30, 286-305.

Suggs, R. C. (1961). The archeology of Nuku Hiva, Marquesas Islands, French Polynesia. Anthropological papers of the American Museum of Natural History. New York: American Museum of Natural History.

Sutton, D. (1987). A paradigmatic shift in Polynesian prehistory: Implications for New Zealand. New Zealand Journal of Archaeology, 19, 135-155.

Taumoefolau, M. (1996). From sau 'ariki to Hawaiki. Journal of the Polynesian Society, 105, 385-410.

Te Rauparaha, T., \& Butler, P. S. (1980). Life and times of Te Rauparaha. Waiura: Alister Taylor.

Turner, M. T. (2000). The function, design and distribution of New Zealand adzes. Unpublished Ph.D., University of Auckland.

Van Dommelen, P. (2014). Moving on: Archaeological perspectives on mobility and migration. World Archaeology, 46, 477-483. doi:10.1080/00438243.2014.933359.

Wallin, P., \& Solsvik, R. (2010). Marae reflections: On the evolution of stratified chiefdoms in the Leeward Society Islands. Archaeology in Oceania, 45, 86-93.

Walls, J. Y. (1974). Argillite quarries of the Nelson mineral belt. New Zealand Archaeological Association Newsletter, 17, 37-43.

Walter, R. (1994). The Cook Islands-New Zealand connection. In D. G. Sutton (Ed.), The origins of the first New Zealanders (pp. 220-229). Auckland: Auckland University Press.

Walter, R. (1998). Anai'o: The archaeology of a 14th century Polynesian community in the Cook Islands., New Zealand Archaeological Association Monograph. Dunedin: New Zealand Archaeological Association.

Walter, R., Jacomb, C., \& Bowron-Muth, S. (2010). Colonisation, mobility and exchange in New Zealand prehistory. Antiquity, 84, 497-513. 
Weisler, M. I., Bolhar, R., Ma, J., St Pierre, E., Sheppard, P., Walter, R., et al. (2016). Cook Island artifact geochemistry demonstrates spatial and temporal extent of pre-European interarchipelago voyaging in East Polynesia. Proceedings of the National Academy of Sciences of the United States of America. doi:10.1073/pnas.1608130113.

Weisler, M. I., \& Walter, R. (2017). East Polynesian connectivity. In T. Hodos (Ed.), The Routledge handbook of archaeology and globalization (pp. 369-386). London: Taylor \& Francis.

Whyte, A. L. H., Marshall, S. J., \& Chambers, G. K. (2005). Human evolution in Polynesia. Human Biology, 77, 157-177. doi:10.1353/hub.2005.0045.

Wilmshurst, J. M., \& Higham, T. F. G. (2004). Using rat-gnawed seeds to independently date the arrival of Pacific rats and humans in New Zealand. The Holocene, 14, 801-806.

Worthy, T. H., \& Holdaway, R. (2002). The lost world of the Moa. Christchurch: Canterbury University Press. 